\title{
Anti-firming Efficiency of Food Emulsifiers on Rice Starch Gel
}

\author{
Keiko Katsuta, ${ }^{*}$ Kazumi Tsutsui, Etsuko Maruyama and Makoto Miura ${ }^{1}$ \\ Department of Food Science and Nutrition, School of Human Life and Environment, Nara Women's University \\ (Kitauoya-Nishi Machi, Nara 630-8506, Japan) \\ ${ }^{1}$ Laboratory of Food and Health Science, Department of Agro-bioscience, Faculty of Agriculture, \\ Iwate University (3-18-1, Ueda, Morioka 020-8550, Japan)
}

\begin{abstract}
The effects of emulsifiers on starch retrogradation and/or firming were investigated by kinetic treatment of static viscoelastic parameters for non-glutinous rice starch gels (30\%). The anti-firming ability of the sucrose mono ester of various fatty acids (C8 through $\mathrm{C} 18$ ) increased with increasing fatty acid chain length, and possessed maximal efficiency at palmitate (C16) ester. However, the ability of food grade emulsifiers consisting of a mixture of stearate and palmitate $(70: 30)$ and having various hydrophilic residues was not proportionally affected to an amylose complexing ability, but strongly influenced by hydrophile-lipophile balance (HLB) values. Among sucrose esters having varied HLB values, the best anti-firming ability was obtained when HLB value was 11 . These results suggest that the anti-firming efficiency of emulsifiers on starch gels might be attributed to the multiple effects between the amylose or amylopectin forming complexes with the lipophilic portion (fatty acid), and the hydration of the hydrophilic portion with water molecules in the starchwater systems.
\end{abstract}

In our previous study on the effect of saccharides on the retrogradation of rice starch by the kinetic treatment for firming process, ${ }^{1-3)}$ we reported the following: 1) saccharides stabilized the gel matrices in the starch-water system and retarded the firming; 2) the ability of saccharides in impeding the retrogradation was closely related to the stereochemical conformation of saccharides; and 3) the maltotriose possessed the maximal ability in impeding the retrogradation of starch. From these results, it was considered that the stability of starch gel was influenced by the state of water in the system, because the spin-spin relaxation times $\left(\mathrm{T}_{2}\right)$ of the retrograded starch gel with maltose and glucose were reduced compared to that of the control gel. ${ }^{4)}$

The food emulsifiers also retarded the firming of rice starch. ${ }^{5)}$ The ability has been explained in previous reports as an adsorption of emulsifier on the surface of the starch granule. ${ }^{6,7)}$ More recent re-

* Corresponding author. (k. katsuta@cc.nara-wu.ac.jp) search has demonstrated that retardation might be attributed to formation of insoluble inclusion compounds such as amylose-lipid complexes. ${ }^{8-13)}$ It has been reported that amylopectin also form the complexes with emulsifiers. ${ }^{14-16)}$ Various emulsifiers have been practically used in the processing of starchy foods to prevent the retrogradation, ${ }^{10}{ }^{10}$ but emulsifiers do not always possesses the same efficiency in impeding the starch retrogradation. This ability may be affected by the composition and/or stereochemical conformation of the emulsifiers, especially regarding the hydrophilic portion. The degree of esterification and the chain length of the lipophilic portion (fatty acid, in the case of food emulsifiers) of emulsifiers are also important factors. In order to clarify the impeding effects of emulsifiers on retrogradation of starches, the influences of these factors must be systematically investigated.

In this study, therefore, various food emulsifiers having different hydrophilic components, sucrose mono esters with various fatty acids and sucrose 
esters with different hydrophile-lipophile balances (HLB) were added to rice starch-water system, and kinetic treatment has been done on the basis of the viscoelastic parameter in order to clarify the factors of which influence the anti-firming effect of emulsifiers on starch.

\section{MATERIALS AND METHODS}

Materials. Non-glutinous rice starch obtained from Matsutani Kagaku Kogyo Co., Ltd. (Tokyo, Japan) was used. The composition of the starch was as follows: crude starch: $86.9 \%$, water: $12.5 \%$, crude protein: $0.3 \%$, crude fats: $0.1 \%$, ash: $0.2 \%$. The diameter of starch granules was $3-8 \mu \mathrm{m}$.

The emulsifiers were used without further purification. The sucrose mono esters (SMCs) of various fatty acids obtained from Mitsubishi Kasei Foods Co., Ltd. (Tokyo, Japan), which SMCs consisted almost $100 \%$ of monoester and various fatty acids, caprylic (C8), capric $(\mathrm{C} 10)$, lauric $(\mathrm{C} 12)$, palmitic (C16) and stearic (C18) acid. Food grade emulsifiers, consisting of a mixture of approximately $70 \%$ stearic and $30 \%$ palmitic acid (with the exception of sodium stearoyl lactylate (SSL)), and having various hydrophilic residues, are shown in Table 1. Glyceryl monostearate (GMS) was obtained from Tokyo Kasei Kogyo, Co., Ltd. (Tokyo, Japan), poly (deca)-glyceryl monostearate (PoGS) from Nikko Chemicals Co., Ltd. (Tokyo, Japan), diacetyl tartric acid esters of mono glycerides (DATEM) and succinylated monoglycerides (SMG) from Riken Vitamin Co., Ltd. (Tokyo, Japan), sorbitan ester of stearic acid (SOES) and polyoxyethyren sorbitan monostearate (POESE) from Kao Co., Ltd. (Tokyo, Japan), and SSL from Musashino Chemicals Lab. Co., Ltd. (Tokyo, Japan). Table 2 shows the sucrose esters (SEs) having different monoester contents (i.e., different HLB values), which were obtained from Mitsubishi Kasei Foods Co., Ltd. (Tokyo, Japan).

Preparation of starch gels. Thirty percent (w/ w) rice starch gels were prepared according to the procedure described in our previous papers. ${ }^{1-4)}$ Rice

Table 1. Abbreviations and data for emulsifiers (stearate esters).

\begin{tabular}{lccc}
\hline \multicolumn{1}{c}{ Emulsifier } & Abbreviations & $\begin{array}{c}\text { Content of } \\
\text { stearate (\%) }\end{array}$ & $\begin{array}{c}\text { HLB } \\
\text { value }\end{array}$ \\
\hline $\begin{array}{l}\text { Glyceryl monostearate } \\
\text { Decaglýceryl monostearate }\end{array}$ & GMS & 69.9 & 3.7 \\
$\begin{array}{c}\text { Diacetyl tartric acid esters of } \\
\text { monoglycerides }\end{array}$ & PoGS & 70.0 & 12 \\
$\begin{array}{l}\text { Succinylated monoglycerides } \\
\text { Sorbitan esters of stearic acid }\end{array}$ & (POEM W-10) & 70.0 & 9.2 \\
$\begin{array}{ccc}\text { SMG } \\
\text { Polyoxyethyren (20) sorbitan }\end{array}$ & SOES & 70.0 & 5.5 \\
monostearate & POESE & 70.0 & 4.7 \\
Sodium stearoyl-2-lactylates & (Tween 60) & 70.0 & 14.9 \\
\hline
\end{tabular}

Table 2. Abbreviations and data for emulsifiers (food grade sucrose esters).

\begin{tabular}{|c|c|c|c|c|c|c|}
\hline \multirow{2}{*}{ Abbreviation } & \multicolumn{2}{|c|}{ Approximate content (\%) } & \multicolumn{3}{|c|}{ Composition of esters (\%) } & \multirow{2}{*}{$\begin{array}{l}\text { HLB } \\
\text { value }\end{array}$} \\
\hline & Stearate & Palmitate & mono & di & tri & \\
\hline SES-1670 & 70 & 30 & 75.9 & 20.1 & 4.0 & 16 \\
\hline SES-1570 & 70 & 30 & 70.1 & 23.8 & 6.2 & 15 \\
\hline SES-1170 & 70 & 30 & 58.8 & 29.4 & 11.8 & 11 \\
\hline SES-970 & 70 & 30 & 49.1 & 31.2 & 19.7 & 9 \\
\hline SES-770 & 70 & 30 & 41.4 & 32.8 & 25.8 & 7 \\
\hline SES-570 & 70 & 30 & 28.9 & 35.2 & 35.9 & 5 \\
\hline SEP-1570 & 30 & 70 & 70.1 & 24.2 & 5.7 & 15 \\
\hline
\end{tabular}


starch was weighed into a flask, and doubly distilled water containing emulsifiers was added to the flask, the suspension was degassed while stirring for $90 \mathrm{~min}$, then the starch suspension was heated at $55^{\circ} \mathrm{C}$ for $3 \mathrm{~min}$ to obtain the homogeneous sol state. The starch sol was poured into glass tubes precoated with the coating reagent Sigma-coat (Sigma Co., St. Louis, MO, USA) and heated at $95^{\circ} \mathrm{C}$ for $90 \mathrm{~min}$. Prior to heating, silicone oil was dropped onto the surface of samples to prevent the evaporation of water during heating. The glass tubes filled with gel samples were sealed, cooled at room temperature for $15 \mathrm{~min}$, and stored at $0^{\circ} \mathrm{C}$.

In most cases of fat-derived emulsifiers, $\alpha$ crystallinity has been found to be important in securing the best anti-firming effect of emulsifiers in starchy foods. ${ }^{10)}$ Just before preparing the starch suspension, emulsifiers were dispersed as follows, to ensure the $\alpha$-crystallinity state: doubly distilled water was added little by little into emulsifiers, which were then mixed for $15 \mathrm{~min}$, heated to $60^{\circ} \mathrm{C}$ until a translucent dispersion was formed, and stirred again for $30 \mathrm{~min}$ at room temperature $(25$ $\left.{ }^{\circ} \mathrm{C}\right)$.

Static viscoelastic measurements. The samples stored at $0^{\circ} \mathrm{C}$ were removed from the incubator after different storage times up to $3000 \mathrm{~min}$, carefully removed from the tubes, cut into cylindrical blocks $(11 \phi \times 10 \mathrm{~mm})$ using a Ultrasonic SampleCutter (USC-3305, Yamaden Co., Ltd., Tokyo, Japan) to produce smooth surfaces, and submitted to creep measurement. A Creep Meter (Rheoner RE33005, Yamaden Co., Ltd., Tokyo, Japan) was used for measurements of the static viscoelastic property (creep) of gels. Measurements were made under uniaxial compression for $300 \mathrm{~s}$ at $25^{\circ} \mathrm{C}$ while ensuring that subsequent deformation was maintained at less than $10 \%$, as the linearity between stress and strain was maintained. ${ }^{1)}$

The five or six cylindrical blocks having specific storage times were measured, and consecutive examinations up to $3000 \mathrm{~min}(50 \mathrm{~h})$ were repeated for at least three cycles.

Kinetic treatments. In our previous report, ${ }^{1)}$ we proposed that the retrogradation and/or firming process of rice starch gels in the initial stage could be expressed by a first-order kinetic equation, as follows:

$$
\log J=-k \cdot t+\log J_{0}
$$

where $k$ is the rate constants (i.e., retrogradation (firming) rate), $t$ is the storage time at $0^{\circ} \mathrm{C}$ and $J_{0}$ is the initial creep compliance (i.e., $J$ when storage time was zero $(t=0))$. In this study, creep compliance, $J$, was used as defined in our previous paper, ${ }^{1)}$ as follows:

$$
J \text { (in this study) }=J(300)-t_{\mathrm{m}} / \eta_{\mathrm{N}}
$$

because the steady (Newtonian) flow part, $t \mathrm{~m} / \eta_{\mathrm{N}}$, is proportionally dependent on the measuring time $\left(t_{\mathrm{m}}\right)$ and is independent from firmness, hence this part has been omitted.

\section{RESULTS AND DISCUSSION}

\section{Kinetic treatment.}

Example plots of $\log J v s$. $t$ for gels containing the $0.5 \%$ (based on the starch weight) food grade sucrose ester of stearate (SES-1570), and the superposed mean value of control (30\% starch alone) are shown in Fig.1. The correlation between $\log J$ and $t$ for the control and the starch-water-SE system are almost linear, showing that the firming process of $30 \%$ rice starch with and without emulsifiers can be described by a first-order reaction equation, as was the case in our previous works. ${ }^{1-3)}$

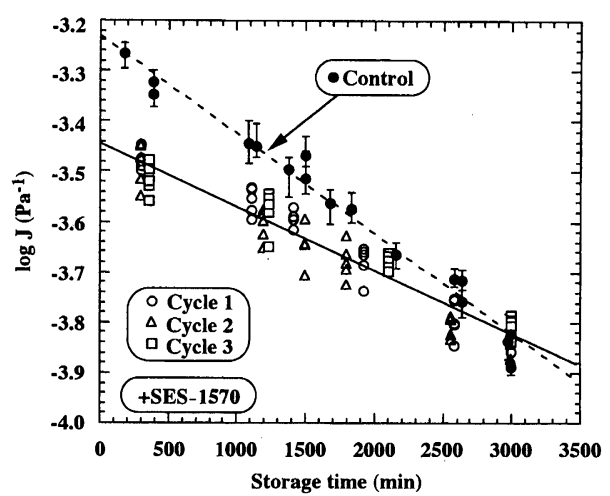

Fig. 1. Changes in creep compliance $(J)$ of $30 \%(\mathrm{w} / \mathrm{w})$ rice starch gel (control) and the gel containing sucrose ester (SE) during storage at $0^{\circ} \mathrm{C}$.

Regression lines are obtained from the data of three cycles. SES-1570, the sucrose ester of fatty acid (stearic and palmitic acid, $70: 30$ ), has an HLB of 15 . The concentration of SE added is $0.5 \%(\mathrm{w} / \mathrm{w})$ of the starch. 
The slope of the line (i.e., firming rate) and the initial $J$ value of the starch-water-SE system were lower than those of the control, indicating that the emulsifier reinforces the gel formation and retards the firming.

\section{Effect of concentration of emulsifiers.}

Before investigating the anti-firming effect of the other emulsifiers, we attempted to determine the optimal concentration. Figure 2 shows the rate constant, $k$, and $J_{0}$ values obtained from gels containing various concentrations of SES-1570 and SEP-1570 based on the starch weight. The hydrophile-lipophile balance (HLB) values of the two SEs are almost the same15). The values of the rate constant $k$ and $\log J_{0}$ of the starch-water-SEs systems decreased rapidly up to $0.2 \%$, gradually passing through the $0.5 \%$ level with increasing concentrations of SEs added. When practical usage for food manufacturing is considered, the addition of too much emulsifier injure the awareness of food attributes (especially, taste). Hence, in the present study, we used $0.5 \%$ of emulsifiers in subsequent experiments. Some differences between the two SEs were observed, suggesting that antifirming efficiency is influenced by the lipophilic part such as the chain length of fatty acids.
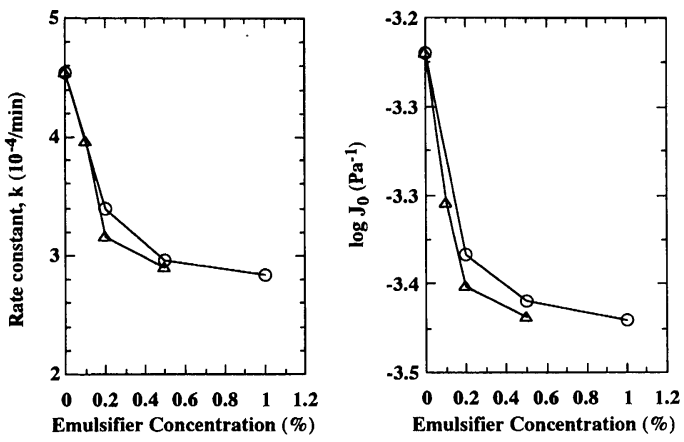

Fig. 2. Effects of SE concentration on firming rate $(k)$ and initial creep compliance value $\left(J_{0}\right)$ in rice starch-water-SE systems.

SES-1570 $(O)$ is the same emulsifier as that shown in Fig. 1, and SEP-1570 $(\triangle)$ is a palmitic-rich emulsifier (palmitic and stearic acid, $70: 30$ ). See Table 2 in details. The concentration of rice starch is $30 \%(\mathrm{w} / \mathrm{w})$.
Effect of fatty acid chain length of emulsifiers on firming kinetics of rice starch.

As mentioned above, the fatty acid chain length of emulsifiers might influence the anti-firming ability, hence, the sucrose monoesters (SMCs) were used. The kinetic parameters, $k$ and $\log J_{0}$, obtained from the gels in the presence of SMCs are plotted as a function of fatty acid chain length (C-atoms) in Fig. 3. The firming rate of the gels decreased with increasing the fatty acid chain length of the emulsifier added, and exhibited a minimal value at $\mathrm{C} 16$.

The initial value of $J$ for the gels containing SMCs shows a maximal peak at SMC12, although the difference between maximal value at SMC12 $(-3.43, \log )$ and minimal value at SMC18 $(-3.52, \log )$ is not so large in comparison with that of the control $(-3.23, \log )$. It is possible that SMCs and GMs may form a supermolecular structure with aggregated complexes, as proposed by Biliaderis and coworkers, ${ }^{12,17,18}$ but $\mathrm{SMC12}$ may have a tendency to form less stable structure than the other SMCs.

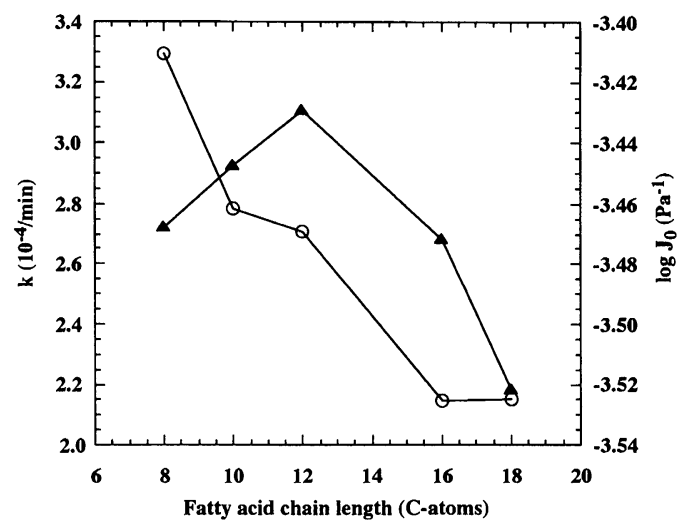

Fig. 3. Effects of fatty acid chain length in sucrose monoesters (SMCs) on firming rate $(k)$ and initial creep compliance value $\left(J_{0}\right)$ for rice starch-waterSMCs systems.

The firming rate $(\bigcirc)$ and initial creep compliance value (A) are plotted as a function of the number of carbon atoms of fatty acid in SMCs. The concentrations of rice starch and SMCs added are $30 \%(\mathrm{w} / \mathrm{w})$ and $0.5 \%(\mathrm{w} / \mathrm{w}$, of the starch), respectively. 

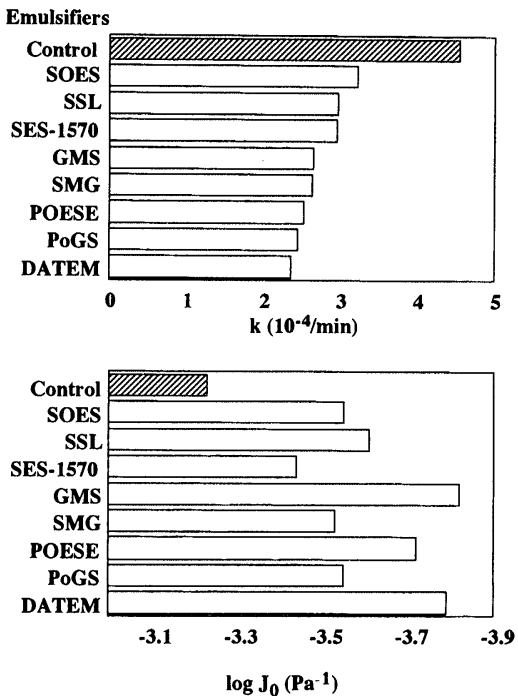

Fig. 4. Firming rate $(k)$ and initial creep compliance value $\left(J_{0}\right)$ of rice starch gels containing various food grade emulsifiers.

The concentrations of rice starch and emulsifiers added are the same as shown in Fig. 3. Information on the emulsifiers is shown in Table 1.

\section{Effect of hydrophilic residues of emulsifiers.}

Next, we investigated the effects of hydrophilic residues of emulsifiers on impeding starch retrogradation. Various food grade emulsifiers, shown in Table 2, were used to prepare the starch-wateremulsifier systems, and the kinetic parameters, $k$ and $\log J_{0}$, are illustrated in Fig. 4, where the data obtained from the gel with SES-1570 (Fig. 1) are also involved. The gels with DATEM showed the smallest firming rate. PoGS also demonstrated good anti-firming efficiency, whereas the antifirming ability of SSL and SOES was poor and that of POESE, SMG, and GMS was intermediate.

In order to consider whether amylose complexes govern the impeding of the retrogradation in the starch-water-emulsifiers system, the data obtained here were correlated to the amylose complexing index with emulsifiers as reported by $\mathrm{Krog},{ }^{11}$ where commercial emulsifiers containing a mixture of palmitic and stearic acid $(35: 65)$ were used. In Fig. 5, the values of $k$ and $\log J_{0}$ were replotted as a function of the amylose complexing index reported by Krog. ${ }^{11)}$ The amylose complexing index of decaglycerol monoester was not investigated in

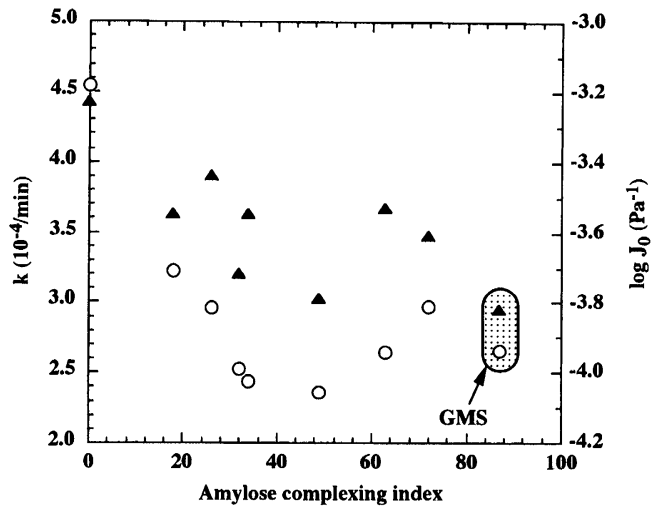

Fig. 5. Plots for firming rate $(k)$ and initial creep compliance value $\left(J_{0}\right)$ of rice starch gels containing various emulsifiers as a function of amylose complexing index.

Amylose complexing indexes used are based on the values reported by Krog. ${ }^{11)}$ The concentrations of rice starch and emulsifiers added are the same as shown in Fig. 3. $\bigcirc$ and $\boldsymbol{\Delta}$ denote firming rate $(k)$ and initial creep compliance value $\left(J_{0}\right)$, respectively.

Krog's paper, but that of tetraglycerol monoester was reported, hence the value with tetra one was used in Fig. 5. Obviously, the firming rates of the gels with emulsifiers did not follow the complexing index, and possess a minimal peak at about $50 \%$ of the magnitude of the index, indicating that the anti-firming ability of emulsifiers on rice starch is not only affected by amylose complexing efficiency but also by other factors.

The anti-firming ability of emulsifiers on rice starch may be affected by their adsorption to starch chains or by the state of water in the systems. Lehmann and Gottschlich ${ }^{19)}$ proposed a schematic figure showing that hydrophilic residues of monoglycerides bind to the amylose surface and form bridges with the micelles of reversed alkylgroups. The existence of such a structural network may impede the re-association of starch chains. However, in our study, DATEM gave the best anti-firming efficiency (Fig. 4). The result indicates that the anti-firming ability of these emulsifiers is not governed by adsorption alone, and suggests that solubility or hydration of emulsifiers may play a role in stabilizing the starch-water systems. Diacetyl tartric acid, as well as saccharides, ${ }^{2}$ may possess structure-making effects on water in 


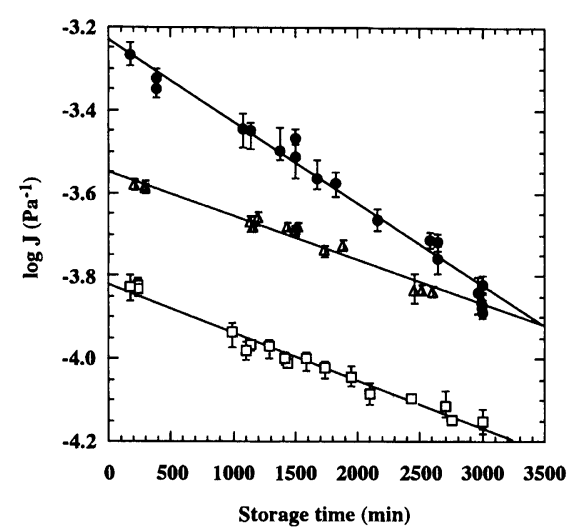

Fig. 6. Changes in creep compliance of $30 \%$ rice starch gel containing glyceryl mono (GMS) and poly (deca: PoGS) esters during storage at $0^{\circ} \mathrm{C}$.

The symbols represent the following; $\bullet$, control (starch gel alone); $\triangle$, PoGS; $\square$, GMS. The concentration of emulsifiers added is $0.5 \%(\mathrm{w} / \mathrm{w})$ of the starch.

the starch-water system. PoGS also possesses good anti-firming ability, whereas the ability of SOES is comparatively low, suggesting that the solubility of emulsifiers in water may play an important role in structure-making on water in the systems. With regard to SSL, it contains $\mathrm{Na}^{+}$ions in the hydrophilic part, leading to an increase in aqueous solubility, but it possesses poor anti-firming efficiency. Ghiasi et al ${ }^{20)}$ found that SSL formed a complex only with amylose, not with amylopectin. This might explain why SSL showed a poor antifirming effect in this study.

Comparing the firming process of the gels with GMS to that with PoGS, the former remarkably shifted to a lower $J$-value (Fig. 6). Actually, the value of $J_{0}$ for the gel with GMS was the lowest among emulsifiers used in the present study (Fig. 4). This suggests that gel matrices are extremely reinforced when GMS enters the rice starch-water systems Biliaderis and coworkers, ${ }^{12,17,18)}$ who studied the starch/mono glyceride complex using mainly DSC and X-ray diffraction, proposed a supermolecular structure of GMS-amylose complexes. Our result obtained with GMS, DATEM and POESE may suggest that the aggregated structure may be involved in the system.

Biliaderis et al. ${ }^{21)}$ also reported that the elevating rate of rigidity obtained from dynamic viscoelastic measurements of wheat starch gels upon addition of GMS and SSL decreased compared to that of the control. However, the initial value of rigidity for gels with GMS was almost the same, and that with SSL was larger than the control, which results were in contrast to ours. Thus, several complicated factors must be involved in the antifirming effect of food grade emulsifiers on starch, though HLB may be predominant factor.

\section{Effect of hydrophile-lipophile balance (HLB).}

It is well known that the HLB value is a practical and industrial index of functionality, especially for solubility of emulsifiers, as initially proposed by Griffin ${ }^{22)}$ and defined as follows:

$$
\text { HLB value }=20 \times(M H / M)
$$

where $M$ is the molecular weight of the emulsifiers and $M H$ is the molecular weight of the hydrophilic part. In general, HLB value is controlled by altering the monoester contents of emulsifiers. SE is a good emulsifier for use in investigating the influence of HLB, because commercial products having different HLB values (1 through 16) are manufactured on the basis of composition of esters in SEs. Hence, we tried to confirm the existence of an optimal HLB in the anti-firming effect of emulsifiers on starch, using several sucrose esters of stearates, SES-1670, -1570, -1170, -970 and -570 (see Table 2). As a SES-1370 is not manufactured, we used an equal mixture of SES-1570 and -1170 to represent SES-1370. As shown in Fig. 7, the minimal value of $k$ and $J_{0}$ were observed when rice starch gels were prepared with an addition of SES-1170 (HLB $=11$ ).

Deffenbaugh and co-workers ${ }^{23)}$ investigated the effects of emulsifiers on pasting properties by Rapid Visco-Analyser testing of several starches with the addition of SEs having HLB values of 6 , 11 and 16 , respectively, but they did not find regularity of the influence of HLB values on the setback of starch pastes. In contrast, as shown in Fig. 7, the SEs show the best anti-firming efficiency for starch when the balance of the hydrophilic and the lipophilic parts are approximately equal.

Finally, the HLB values of SMCs were calcu- 


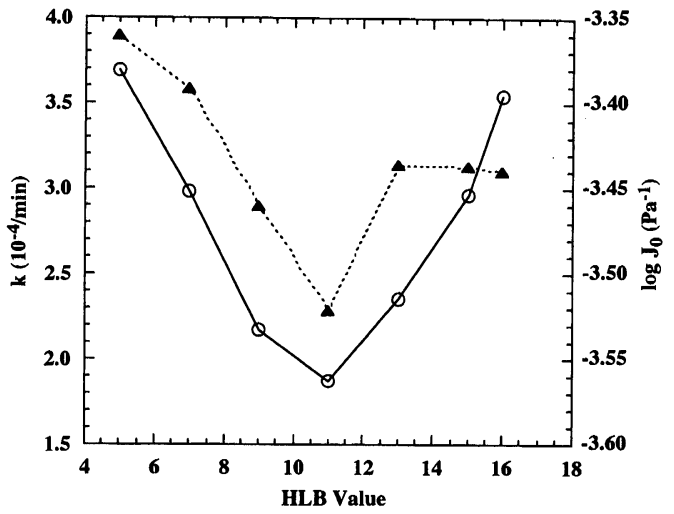

Fig. 7. Plots for firming rate $(k)$ and initial creep compliance value $\left(J_{0}\right)$ of $30 \%$ rice starch gels containing various sucrose esters (SEs) as a function of HLB values.

Information on SEs is shown in Table 2. The concentration of SEs added is $0.5 \%(\mathrm{w} / \mathrm{w})$ of the starch. $\bigcirc$ and $\Delta$ denote firming rate $(k)$ and initial creep compliance value $\left(J_{0}\right)$, respectively.

lated by Eq.(3), and the firming rates obtained from the gels with the respective emulsifiers used in the present study were overplotted as a function of HLB value, as shown in Fig. 8. The results strongly support the hypothesis that maximal antifirming efficiency of the emulsifier could be obtained at an HLB value of around 10. The result suggests that emulsifiers acquire the most antifirming ability from the multiple effects between the amylose or amylopectin complex-forming with fatty acid and the hydration of the hydrophilic portion with water molecules when the lipophilic and hydrophilic parts are almost equal. This suggestion should be confirmed using analytical measurements such as pulsed NMR, X-ray diffraction, and/or polarized optical microscopic observation. We intend to undertake these measurements, involving the effect of dynamic viscoelastic properties and thermal properties by DSC on the process of gelatinization, using defatted starch. The rice starch used herein was not defatted because of its low fat content $(0.1 \%$ crude fat).

\section{CONCLUSION}

In this study, emulsifiers possessed an antifirming efficiency on rice starch during storage.

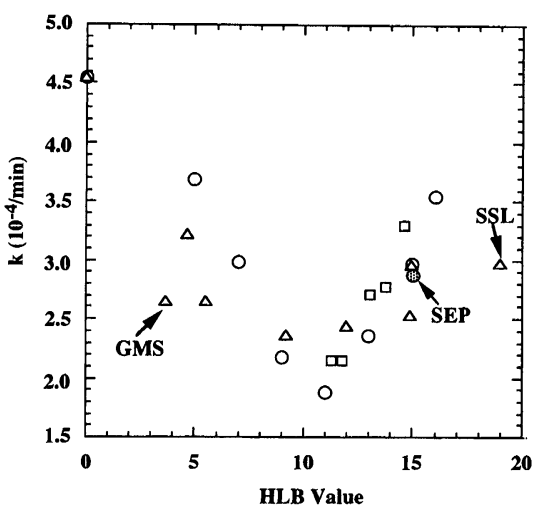

Fig. 8. Over-plots for firming rate $(k)$ of $30 \%$ rice starch gels containing respective emulsifiers as a function of HLB values.

The symbols show as follows; $O$, SEs (Table 2); $\Delta$, food grade emulsifiers (Table 1); $\square$, SMCs. The HLB values of SMCs are calculated by Eq. (3).

The ability of emulsifiers was not governed by the amylose-complexing index but strongly influenced by HLB value, and the best anti-firming ability was obtained with an HLB value of around 10 . This indicates that the hydrophilic part of the emulsifiers, as well as lipophilic portion, plays an important role in stabilizing the gel matrix, and that emulsifiers show the best anti-firming ability when the lipophilic and hydrophilic parts are almost equal.

We thank Ms. J. Masumura, K. Kinoshita and S. Yagi for their technical help. Support of the present research by Mitsubishi Chemical Co. is gratefully acknowledged.

\section{REFERENCES}

1) K. Katsuta, M. Miura and A. Nishimura: Kinetic treatment for rheological properties and effects of saccharides on retrogradation of starch gels. Food Hydrocolloids, 6, 187-198 (1992).

2 ) K. Katsuta, A. Nishimura and M. Miura: Effects of stabilities of rice starch gels. 1. mono- and disaccharides. Food Hydrocolloids, 6, 387-398 (1992).

3 ) K. Katsuta, A. Nishimura and M. Miura: Effects of stabilities of rice starch gels. 2. oligosaccharides. Food Hydrocolloids, 6, 398-408 (1992).

4 ) K. Katsuta: Effects of salts and saccharides on rheological properties and pulsed NMR of rice starch during gelatinization and retrogradation. in Gums and Stabilizers for the Food Industry, 9, P.A. Williams 
and G.O. Phillips, eds., The Royal Society of Chemistry, Cambridge, pp. 59-68 (1998).

5 ) M. Miura, A. Nishimura and K. Katsuta: Influence of addition of polyols and food emulsifiers on the retrogradation rate of starch. Food Struct., 11, 225-236 (1992).

6 ) L. Lehrman: The nature of fatty acids associated with starch: The adsorption of palmitic acid by potato and defatted corn and rice starches. J. Am. Chem. Soc., 64, 2144-2146 (1942).

7 ) R.L. Whistler and G.E. Hilburt: Extraction of fatty substance from starch. J. Am Chem. Soc., 66, 17211722 (1944).

8 ) E.M. Osman, S.J. Leith and M. Fles: Complexes of amylose with surfactants. Cereal Chem., 38, 449-454 (1961).

9 ) H.F. Zobel: X-ray analysis of starch granules. Methods Carbohydr. Chem., 4, 109-113 (1964).

10) N. Krog and B. Nybo-Jensen: Interaction of monoglycerides in different physical states with amylose and their anti-firming effects in bread. J. Food Technol., 5, 77-87 (1970).

11) N. Krog: Amylose complexing effect of food grade emulsifiers. Starch, 23, 206-210 (1971).

12) C.G. Biliaderis, C.M. Page and T.J. Maurice: On the multiple melting transitions of starch/monoglyceride system. Food Chem., 22, 279-295 (1986).

13) A.-C. Eliasson and N. Krog: Physical properties of amylose-monoglyceride complexes. J. Cereal Sci., 3, 239-248 (1985).

14) J. Lagendijk and H.J. Pennings: Relation between complex formation of starch with monoglycerides and the firmness of bread. Cereal Sci. Today, 15, 354356, 365 (1970).

15) M. Matsunaga and K. Kainuma: Studies on the retrogradation of starch in starchy foods. part 3. Effect of the addition of sucrose fatty acid ester on the retrogradation of corn starch. Starch, 38, 1-6 (1986).

16) J.J. Huang and P.J. White: Waxy corn starch: Monoglyceride interaction in a model system. Cereal Chem., 70, 42-47 (1993).

17) C.G. Biliaderis and H.D. Seneviratne: On the supermolecular structure and metastability of glycerol monostearate-amylose complex. Carbohydr. Polym., 13, 185-206 (1990).

18) C.G. Biliaderis and H.D. Seneviratne: Solute effects on the thermal stability of glycerol monostearateamylose complex superstructure. Carbohydr. Res., 208, 199-213 (1990).
19) V.G. Lehmann and H. Gottschlich: Effects of Emulsifiers on Starch. Fette. Seifen. Anstrichmittel, 85, 439443 (1983).

20) K. Ghiasi, E. Varriano-Marston and R.C. Hoseney: Gelatinization of wheat starch. II. Starch-surfactant interaction. Cereal Chem., 59, 86-88 (1982).

21) C.G. Biliaderis, D.J. Prokopowich, M.R. Jacobson and J.N. BeMiller: Effect of $n$-alkyl glucosides on waxy maize and wheat starch retrogradation. Carbohydr. Res., 280, 157-169 (1996).

22) W.C. Griffin: Classification of surface-active agents by "HLB". J. Soc. Cosmet. Chem., 1, 311-325 (1949).

23) L.B. Deffenbaugh, N.E. Lincoln and G.E. Walker: Use of the rapid visco-analyser to measure starch pasting properties. Part II. Effects of emulsifiers and sugar-emulsifier interactions. Starch, 42, 89-95 (1990).

(Received April 6, 2001; Accepted December 10, 2001)

\section{米澱粉ゲルに及ぼす乳化剤の硬化抑制効果}

勝田啓子, 筒井和美 丸山悦子, 三浦 靖1

$$
\begin{gathered}
\text { 奈良女子大学生活環境学部 } \\
\text { (630-8506 奈良市北魚屋西町) } \\
1 \text { 岩手大学農学部 } \\
\text { (020-8550 盛岡市上田 3-18-1) }
\end{gathered}
$$

30\%（w/w）粳米澱粉ゲルの静的粘弾性パラメータ の速度論的処理を基に，澱粉老化（硬化）に及ほす乳 化剂の影響を検討した．脂肪酸（C8-C18）組成の異な るモノシュガーエステルの硬化抑制能は脂肪酸鎖長の 増大につれて大となり，パルミチン酸エステルで最大 となった．しかし，脂肪酸がステアリン酸: パルミチ ン酸 $=70: 30$ の混合で親水基の異なる各種食用乳化剂 の硬化抑制能は, アミロース複合体形成指数とは比例 せず，HLB 值に強く影響された，HLB 值の異なるシュ ガーエステルでの検討の結果，HLB が11のものが最 良の硬化抑制効果を示した。これらの結果は，澱粉の 老化における乳化肪の硬化抑制効果は，疎水部(脂肪 酸）のアミロースあるいはアミロペクチンとの複合体 形成性と，親水部の水との水和の複合的な作用によっ て引き起こされるということを示唆している。 